\title{
Animal Genomics in Science, Social Science and Culture
}

\author{
MATTHEW HARVEY ${ }^{1}$
}

\begin{abstract}
Animals are commonplace in genomic research, yet to date there has been little direct interrogation of the position, role and construction of animals in the otherwise flourishing social science of genomics. Following a brief discussion of this omission, I go on to suggest that there is much of interest for the social sciences and the humanities in this field of science. I show that animal genomics not only updates and extends established debates about the use of animals in science and society, but also raises novel issues and promotes new ways of thinking about what animals are, and the social and biological relationships between animals and humans. Organising the science of interest into six themes (sameness, difference and classification; crossing boundaries; the maintenance of borders; farmyard supermodels; laboratory supermodels; knowing, relating and looking at animals), for each I review some of the science that is being done, some of the conceptual issues that are raised, and some of the social science that is or could be done. I conclude by briefly considering the development of socially responsive policies for animal genomics.
\end{abstract}

\section{Introduction}

Animals are commonplace in genomic and biotechnological research, as principal objects of study or conduits and models for understanding human biology. This work connects with longstanding debates about the use of animals in science and society, extending and updating these with new techniques for understanding and using animals. But further, the science of genomics and the manipulation of animal genomes raises novel issues and promotes new ways of thinking about what animals are, how they evolve and relate to each other, and the social and biological relationships between animals and humans. Yet there is little direct interrogation of animal genomics in the social science literature, particularly if genomics is conceived only as the DNA sequencing of the entire genome. There is a growing literature for research agendas within the broader field of biotechnology, in particular xenotransplantation and genetically modified animals, ${ }^{2}$ and human-animal chimeras and cloning have also received some attention. ${ }^{3}$ But to date, the key arena for discussing developments like these remains ethics and bioethics. ${ }^{4}$

Following a note on the meaning of "animal genomics", this review briefly discusses the broad omission of animals from social science. The paper then goes on to consider the context and shaping of the science of animal genomics, a range of questions and issues for which genomic solutions have been proposed, and how this work might reconfigure the social and cultural position of animals and human-animal relations. Suggesting there is much here of social scientific interest, the paper finally considers policy issues for regulating and governing animal genomics and exploiting animal genomic research. 


\section{Animals, genomics and social science}

Although the term genomics might be restricted to the sequencing of the entire genetic complement of an organism, and so animal genomics might refer only to the genome sequencing of animals, in practice sequencing alone is of little interest. It is what follows that is significant, such as how that knowledge connects with what else is or can be known; how the knowledge so obtained might be applied; or how that animal is better understood in itself or in comparison to others. Sequencing may further be married with other techniques such as genetic modification or selective breeding, and the animal genome worked on and with in new or more intense and efficient ways.

This marriage probably marks the disciplinary boundary of "animal genomics". But for this paper I will conceive the field of interest more broadly still, for there are now practices where the genomes, genes and tissue of particular species turn up in novel and unexpected places, such as in xenotransplantation and stem cell research. For example, human embryonic stem cells have recently been implanted into, and have then integrated with, mice brains. ${ }^{5}$ The transplanted tissue is then a metonym for the animal or species from which it came, and the power of the connection is hard to erase, perhaps notably so if that animal's genome has moved too. If animal genomics is thought of in these terms, broader than mere sequencing to encompass working on and with animal genomes, then as I go on to show and explain, the depth and significance of activities within animal genomics is extensive.

This science uses and impacts on a lot of animals, including ourselves. Despite this, and with work reported in the present volume excepted, there is little direct work within social science on animal genomics as a topic in its own right. The work published so far has concentrated on certain hard cases - xenotransplantation, genetic modification, cloning - that have been opened up to public debate or seem particularly problematic in terms of ethics or regulation. Moreover, this research has usually been limited to what these practices might mean for people. For example, Michael argues that the 'technoscientific bespoking' of animals by making them 'ready-to-order ... might catastrophically curtail the symbolic role of animals in human identities, and thus provoke a general anxiety toward new genetics' ${ }^{6}$ What is happening to the animal is inconspicuous.

This omission, perhaps, reflects a broader circumstance within social science, for animals remain in the social science literature largely invisible and 'to read most sociological texts, one might never know that society is populated by non-human as well as human animals'. ${ }^{7}$ There is substantial work within other related disciplines such as moral philosophy ${ }^{8}$ and history, ${ }^{9}$ and some of this crosses with sociological accounts ${ }^{10}$ and has considered the impact of biotechnology. ${ }^{11}$ But, historical accounts aside, this work has generally been balanced toward an animal rights or ethical frame. Tester, for example, explores the way that society and individuals relate to animals, but his primary concern is with special claims made for animal rights. ${ }^{12}$

Recently, some social scientists have attempted to account for animals' invisibility, suggesting that animals tend to be embedded and treated within the broad category

Genomics, Society and Policy, Vol.3, No.2 (2007) ISSN: 1746-5354

(C) ESRC Genomics Network. 
"nature" or that social science is person-centred and animals, considered not part of society, are of little interest. ${ }^{13}$ Moreover, a social science of human-animal relations has recently expanded, ${ }^{14}$ and there is a large and developed literature on relations between humans and companion animals. ${ }^{15}$ But this attention has not yet transferred to the otherwise flourishing social science of genomics ${ }^{16}$ and the general lack of attention becomes all the more interesting given the integral position of animals in the genomics revolution (assuming there is such a revolution) and many other social and scientific practices. ${ }^{17}$

Paula offers some of the clearest examples of published research with an explicitly animal-genomic orientation, considering the impact of genomic approaches in the context of food production and policy development. ${ }^{18}$ However, a broader research agenda that captures a wider range of genomic sciences and which considers the human, the animal, and the human-animal conceptual coupling is required, one which is unlikely to emerge simply from the aggregate of those individual projects currently represented in the literature. In the following section I outline six themes emerging from the science of animal genomics, broadly defined, of interest to social science (and to the arts and humanities).

\section{Sameness, difference and classification}

'Much of nature', comments Stephen Jay Gould, 'is messy and multifarious, markedly resistant to simple mathematical expression'. ${ }^{19}$ But rather than being an obstruction to science, this amounts to its challenge, and genomics has become part of the scientific project that tries to turn nature, by which I mean here the plants, animals and other features and products of the earth, into something orderly and simple. Two particular and stubborn types of problem, presented by the mess and complexity of nature as well as by its size and spread, now have apparent genomic solutions and even mathematical articulation. The first concerns the recording and cataloguing of biodiversity, the second its classification.

\section{Species identification and recording biodiversity}

How does one determine of which known species a particular specimen is an example, or indeed if that specimen is "new to science"? Species identification is primarily based on visible morphology but the technique remains problematic. For example, Hebert et al point out that even the best taxonomists can identify just a tiny percentage of the estimated 10-15 million species on Earth, and morphological keys used in identification require such a high level of expertise that misdiagnoses are common. Further, variation between individual members of a species can lead to misidentification, and morphology can differ significantly across the life-span making correct identification difficult. Some species are morphologically cryptic, that is, so similar that it is nearly impossible to distinguish between them, and even if other factors like internal anatomy, behaviour and geography can be taken into consideration, Hebert et al note that 'although much biological research depends on species diagnosis, taxonomic expertise is collapsing, ${ }^{20}$ To resolve the problem, they propose that short DNA sequences known as "barcodes" offer the best approach to a sustainable identification system.

Genomics, Society and Policy, Vol.3, No.2 (2007) ISSN: 1746-5354

(C) ESRC Genomics Network. 
DNA barcoding assumes that a simple and unique DNA sequence can distinguish and therefore identify any given species, and the search is underway for a sufficiently standardised yet discriminatory section of DNA. Early attempts resulted in some failures, classifying ladybird beetles as wasps, for example, ${ }^{21}$ but a 648 base pair region of the cytochrome $c$ oxidase I (COI) mitochondrial gene has been shown to be particularly promising in tests with birds, fishes and some orders of insects. ${ }^{22}$

Barcoding every species would help field scientists identify specimens, but social scientists might note that the technique has social and policy implications. For example, barcoding may facilitate the monitoring of species, feeding into current societal and policy concerns over conservation, the maintenance of biodiversity and the tracing of foodstuffs (on the latter, see section 3 below). For example, a group attempting to barcode all fish argue that such data would assist sustained fisheries management and consumer confidence. ${ }^{23}$

But the promissory future for barcoding transcends identification and monitoring, and the vision is for nothing short of a barcoded world. There is now a strong and developing research network - the Consortium for the Barcode of Life ${ }^{24}$ - and reports suggest that a Canadian team will have barcoded every known bird in the world by 2010 . $^{25}$ Once a comprehensive species catalogue has been compiled, it could then be made instantly accessible. Paul Hebert, barcoding's chief protagonist, envisions a day 'when every curious mind, from professional biologists to schoolchildren, will have easy access to the names and biological attributes of any species on the planet' ${ }^{26}$ This will have implications for public understanding and engagement with science, and sociologists of science may also note that barcoding has generated debate within scientific circles on its economic and technical footing as well as its consequences for traditional taxonomy and taxonomists. ${ }^{27}$ There is presently no social scientific interest in this fascinating and growing field, but if realised, the claims of the barcoding community will be socially, politically and conceptually significant. ${ }^{28}$

\section{Species and classification}

For Will et al, 'DNA barcoding has both new and good elements, but unfortunately no elements that are both'. ${ }^{29}$ Ebach and Holrege are similarly dismissive, arguing that barcoding generates only information not knowledge, and tells us little more than we know already: 'life is complex'. ${ }^{30}$ In particular, whilst barcoding may lend itself to identification under conditions of uncertainty, it has less application to some other goals of taxonomy such as classifying organisms and describing relations between them. Classifying and relating are particularly hard problems, but where the limits of barcoding are reached, other genome-based solutions are encountered.

Ritvo notes a persistent paradox: it is obvious that human beings are different from non-human animals but it is not obvious what the kind and degree of difference is. ${ }^{31}$ This problem of determining sameness and difference extends to all other relations between members of the animal kingdom, and Ritvo records some of the many ways that, historically, these differences have been discussed and turned into systems of classification. ${ }^{32}$ As a systematised scientific endeavour, classification - the practical 
activity of assigning the vast numbers of organisms in the world to particular kinds can trace its roots to the enlightenment and has turned up many competing schemes. But that there have been (and are) competing schemes and taxonomies supports Ritvo's general point that classification, and description of sameness and difference, reflects intellectual, social and political commitments as much as, or more than, what differences there "really" are.

For some, any difficulty in a satisfactory final classification scheme of all animals should be circumvented (and explained) by considering classification as a pragmatic and pluralist practice. Dupré argues that diverse sets of people - biologists, ecologists, foresters, gamekeepers, wildflower enthusiasts, members of the public and so on require workable classifications, but classifications that need not necessarily align. ${ }^{33}$ No particular scheme should be privileged, and Dupré argues that ordinary-language or folk taxonomies can be treated on a par with, and in the same way as, scientific classifications. For example, Dupré suggests there is no sound reason to exclude whales from the category fish, except the consensual agreement that they are not. Prior to science, whales were fish but folk were 'duped into changing that belief for bad reasons. ${ }^{34}$

Dupré acknowledges that this claim is controversial, but to say that there is no unique and privileged biological (ie, within science) classification is less so. An underlying difficulty (but one that does not trouble barcoders) is that there is no current solution to the 'famously difficult' species problem; that is, the failure of biologists to agree on how we should define the word "species" and therefore the grounds on which we should make species discriminations. ${ }^{35}$ A popular solution is to consider two populations of sexually reproducing organisms as different species if they cannot interbreed with each other. But this only accounts for sexually reproducing organisms, of which many living organisms including many plants are not, so a different concept is needed for them. Also, as Hey points out, some breeds of dog can mate but some cannot (because of extreme size differences) leaving it open whether 'dog' is a term for many different or one species. These, and other problems, mean that there are some two dozen different definitions of "species". ${ }^{36}$

For Hey, much of the difficulty comes in the deployment of rival and fuzzy linguistic categories, all of which are assumed to mirror patterns found in nature. But into this uncertain arena, genome sequencing might offer empirical, clarifying data.

Comparing DNA sequences and whole genomes offers the promise of an objective concept for the relationship between organisms, ${ }^{37}$ yet as I will show, it might be just as troubling.

\section{Humans and other animals}

Although there are certainly groups and individuals who would say otherwise, in scientific and much popular parlance humans are animals, even if we might think that humans are particularly distinctive animals. This view is maintained in the current consensual scheme of biological classification and through the theory of evolution. But as already indicated, whilst it is easy to say humans are particularly distinctive

Genomics, Society and Policy, Vol.3, No.2 (2007) ISSN: 1746-5354

(c) ESRC Genomics Network. 
animals, this is the start of many conceptual and empirical difficulties. From a conceptual perspective, Herrnstein Smith writes:

'Once the straightforward truth of our human distinctiveness is unsettled by the straightforward truth of our animal identity, there is no point, or at least no more obviously natural point, beyond which the claims of our kinship with other creatures - or, indeed, beings of any kind - could not be extended; nor, by the same token, is there any grouping of creatures, at least no more obviously rational grouping, to which such claims might not be confined' ${ }^{38}$

For Herrnstein Smith, this invokes a 'chain of animate being', a continuum that can't sensibly be broken up into discrete units toward which different rules of conduct apply. But people frequently act as if it can. Herrnstein Smith refers, for example, to an 'ethical taxonomy' where our sensed and practised responsibilities to horses, butterflies, walruses, oysters, wasps, lice and microbes are quite different.

Extending our moral responsibility to microbes seems absurd, but Herrnstein Smith's point is that there is no obvious point on the continuum to make the break and divide the sensible from the silly. This is a policy as well as a philosophical conundrum, and one discussed in the UK Parliament during a debate on the proposed animal welfare bill. One Member of Parliament noted considerable problems with the definition of "animal" in the bill. For the purposes of the bill, the category "animal" contains only vertebrates, but the Member argued that if the bill was designed to alleviate the suffering of animals, then it should be extended to those non-vertebrates that scientific evidence suggests are capable of suffering, including cephalopods such as octopus and cuttlefish. ${ }^{39}$ Perhaps then the scientific criteria of "suffering" should replace the scientific category of "vertebrate".

Genome analysis cannot speak directly to such ethical and political questions, but it does have something empirical to say about degrees of difference and relatedness between organisms; a quantitative knife so to speak. One of the less celebrated findings of the human genome project is how few genes humans have. Early estimates suggested up to 200,000 with a concomitant theory that the more complex an organism the more genes it would have (and obviously we would have the most). But this number has steadily dropped to the current estimate of about 25,000, making humans around 3,000 genes different to a worm, 2,000 different to a fruit fly, and 17,000 different to rice, which has more. ${ }^{40}$ This fall required some re-working of the notion of complexity: if humans were to remain the most complex, mere numbers of genes could not be the key. Attention shifted from structure to function and meaning. For example, Enard et al report that human and chimp genomes are 98.7\% identical in their DNA sequence, yet there are many clear differences between the species. ${ }^{41}$ Hypothesising that the underlying basis of these differences is likely to be altered gene expression, they go on to show that large numbers of quantitative changes in gene expression can be detected between closely related mammals. Such changes, they argue, have been particularly pronounced during the evolution of the human brain. $^{42}$ 
Human complexity is thus saved, but $98.7 \%$ still seems to suggest that humans and chimps are mostly the same, a figure that rises to $99.4 \%$ for functionally important sites. 'Chimps are human, gene study implies' read the headline on NewScientist.com when the latter figure $99.4 \%$ was announced, ${ }^{43}$ and for Morris Goodman and colleagues data like this challenges the anthropological view that has traditionally emphasised how very different humans are from all other forms of life. ${ }^{44}$ For Goodman et al, whilst traditionally chimps are classified with gorillas and orang-utans in the family pongidae, separate from the human family hominidae, the DNA data means that chimps must be moved over to the human family: 'The accumulating DNA evidence provides an objective non-anthropocentric view of the place of humans in evolution. We humans appear as only slightly remodelled chimpanzee-like apes'. ${ }^{45}$ That doesn't make us sound particularly special or even distinctive, and Goodman claims anthropologists have their own vested interests for making us seem otherwise. ${ }^{46}$

But what does it mean, based on DNA data, to say that 'chimps are human'? Anthropologist Jonathan Marks argues that similarity in DNA is being casually translated into similarity of "us", but this is just metonymy - replacing one part of us for "us". Moreover, why describe us as a remodelled chimp-like ape? As Marks points out, this is just because we interpret a figure like $98.7 \%$ identity in DNA to mean we are $98.7 \%$ chimp, but on that basis we are also $35 \%$ daffodil, and to say we're quite extensively remodelled daffodils 'is more ludicrous than profound'. ${ }^{47}$

For Marks, to read anything into this is to reduce life to genetics, and genetics has nothing important to say about the differences between humans and animals. A figure like $98.7 \%$ or $99.4 \%$ 'bears the precision of modern technology [and] carries the air of philosophical relevance' but this emperor really has no clothes. ${ }^{48}$ Marks takes to pieces the methodologies of comparative genomics and shows how assumptions stack up to error. He then claims that anyway, there is nothing profound about saying that we are genetically similar yet different to chimps: this is entailed by the theory of evolution. Moreover, there are so many ways that humans are so obviously different to other animals, including the chimpanzee, that what needs explaining is why we are currently bewitched by genetic similarity.

There is no space here to look deeper into the ongoing debate on the significance of DNA comparisons between humans and other animals, save to raise three of many points of interest for the social sciences and humanities. The first is conceptual, for the debate amounts to a struggle for the right to define humanness. Since the 1960s, old questions pertaining to describing and conceptualising the similarities and differences between humans and other animals have begun to be colonised by genome-based sciences and the implications of this for understanding humanness need to be fully worked out. The second and third points, not unrelated, are sociological.

This struggle is as much conceptual as it is territorial, with traditional anthropology, molecular anthropology, molecular biology and comparative genomics amongst those disciplines claiming the right to define what amounts to humanness. This struggle will be of interest to sociologists of science and different techniques, materials and forms

Genomics, Society and Policy, Vol.3, No.2 (2007) ISSN: 1746-5354

(C) ESRC Genomics Network. 
of evidence (palaeontology, genomics, ethnography, bones, DNA and so on) are mobilised by different groups in support of one position or another. But, as suggested, molecular techniques appear to be emerging as markers of the dominant paradigm, and so the third and final question asks why.

With Marks, the colonisation of humanness by genome science might most simply be viewed as an extensively generalised example of the narrative of geneticisation, a term first used by Lippman to refer, in the context of health and disease, to 'an ongoing process by which differences between individuals are reduced to their DNA codes'. ${ }^{49}$ When applied to an understanding of the demarcations between humans and animals, this certainly sounds like what we are talking about. To illustrate, Armand Leroi, a biologist at Imperial College London, explained in a documentary on UK television that we can cast aside all other previously mooted demarcation criteria and simply point to particular genes:

'Ever since Aristotle, philosophers have wondered what makes us different from the beasts. Their answers - that man is a political animal, a thinking animal, a tool making animal - can now be discarded. Now, when we ask what makes us human, we can answer this gene, and that one and that one. We can begin to write the recipe for making a human being. ${ }^{50}$

Accordingly, a research effort is underway to pinpoint the telltale genes. ${ }^{51}$ But to say we now view such differences as genetic because we see everything as genetic is not saying much, and to understand the hold and power of DNA in this case we need to look at something else.

The essence of DNA, no matter how it can be described in biochemical terms, is that it is information. ${ }^{52}$ The drift to information began in 1965 when Zuckerkandl and Pauling stated that the essence of the organism is located in informational macromolecules, particularly DNA. ${ }^{53}$ For them, the only reason we see discrete living forms at all is because of the relatively fixed information passed from generation to generation, information contained in DNA. This encourages a particular view of humanness, an ontological shift perhaps, but Zuckerkandl and Pauling would and probably could not have predicted the transformations in information technology that would come in the following decades, and which would bring DNA to the foreground.

An impressive international effort devoted to the sequencing and digital storage of animal genomes now relies on information technology. Many outputs are made available on publicly accessible databases, and the DNA codes of African savannah elephant, the nine-banded armadillo, the domestic cat, the European rabbit and the northern white-cheeked gibbon were just a few of those to begin to be sequenced in $2006 .{ }^{54}$ Tentatively then, the particular attraction of DNA for conceptualising humanness and relations between animals might be that DNA presents, indeed is, a code that can be read, collated, stored, sorted, compared, manipulated, categorised and accessed in a way not offered by other sources of data. Of all the possible types of data that have or could be used as demarcation criteria between animals - bone, hair, communication, tool use, art, culture, consciousness, reflection, whatever - it is DNA 
that has been selected and harvested, and through the interconnection with information systems, humanness and the essence of animals is quantified and digitized.

The sheer volume of information generated presents significant practical problems: genomes sequenced to date range in size from 100 to a thousand million bytes and just storing genomic information and the results of comparisons is a challenge. ${ }^{55}$ Yet the effort is considered worthwhile, not just because cross-species genome comparisons offer a tool for understanding the genetic factors involved in human health and illness, but that they also offer the chance to complete the annotation of the "tree of life".

\section{The tree (or ring or net) of life}

Phylogenetic trees are schemes that represent evolutionary relationships between organisms, and molecular phylogenetics infers these relationships through comparing DNA sequences. Molecular phylogenetics expanded with DNA sequencing techniques and more so in the 1990s with the rapid sequencing and availability of whole animal genomes. Two basic assumptions are that all species, present and past, share a single common ancestor, and that as time passes new species evolve from earlier ones. If genomes evolve by the gradual accumulation of mutations, then the amount of difference in nucleotide sequence between two genomes indicates how recently those genomes shared a particular common ancestor, with two recently diverged genomes having fewer differences than two that diverged further back in time. ${ }^{56}$ By comparing three or more genomes, the evolutionary relationship between them can be inferred, and in principle, if you carried on doing this for everything it would be possible to construct the universal tree, 'an image that unifies all life through its shared histories and common origin'. 57

But at the same time as showing promise for completing the universal tree, genomics might ultimately undermine this goal. First, different research objectives, methodologies and practices produce different trees, meaning that the (re)construction of evolutionary time, events and relationships remains indeterminate. Second, genomic research suggests that at its very deepest roots, the tree metaphor has to give way to a ring or a net. Darwin made his first (but not the first) sketch of something like an evolutionary tree in his 1837 Notebook on Transmutation of Species, and "tree" is the standard metaphor for evolutionary relationships. ${ }^{58}$ But comparative genomics and the subsequent demonstration of horizontal gene transfer (the transmission of DNA between species) suggest that the "tree of life" depiction of evolution is misleading, or perhaps even meaningless. ${ }^{59}$ Research by Rivera and Lake suggests that the relatively complex genome of eukaryotes (cellular non-bacterial life) arose from the fusion of two simple prokaryote genomes. This, they argue, means that at the deepest levels there is a ring of life with no start and no end. ${ }^{60}$ Alternatively, Kunin et al and Doolittle prefer to talk of a net of life. ${ }^{61}$ Trees only represent linear and vertical relationships, but the net metaphor better captures the transmission of DNA between organisms. 
The increase in resolution afforded by genome analysis therefore challenges orderly, tree-like representations and confirms that nature is messy all along. Doolittle summarises the general situation like this:

\begin{abstract}
'Biologists came to think that ... the ultimate natural order is a single inclusively hierarchical, "universal phylogenetic tree", without reticulation ... If, however, different genes give different trees, and there is no fair way to suppress this disagreement, then a species (or phylum) can "belong" to many genera (of kingdoms) at the same time: There really can be no universal phylogenetic tree of organisms based on such a reduction to genes'. ${ }^{6}$
\end{abstract}

Doolittle suggests that to save the tree concept, organisms could be defined as more than the sum of their genes, having some sort of 'emergent reality' which permits once more expression of relationships to be maintained at the species/organismal level. But if we need to turn to extra criteria, the increasingly technical and quantitative investigation of the relationships between animals from molecular phylogenetics and comparative genomics has brought us no closer to conceptually defining borders between organisms. There is no better demonstration of these emergent realities than when ordinary language classifications, expressed through sensed kinship, are revealed in genomic breaching experiments; that is, scientific practices where borders are transgressed.

\title{
2. Crossing boundaries
}

Robert and Baylis list seven examples of 'novel creatures', real or imagined, which mix biological material across conventional species boundaries, be they animal-toanimal transgenic organisms or nuclear-cytoplasmic hybrids, or human-animal chimeras created by inserting human cellular material into a nonhuman embryo or nonhuman material inserted into adult humans. ${ }^{63}$ What happens when scientists mix tissue from different species into a new whole? Perhaps moral and ethical confusion, queasiness, revulsion, affront to nature, a challenge to humanness and animal integrity? ${ }^{64}$ Perhaps all of these, but perhaps also the betterment of human and animal health, improved animal welfare, or better animal products. ${ }^{65}$

For Cohen, recent technologies that enable the insertion of human cells into animals and vice-versa require the development of a standard for determining where the conceptual boundary between humans and animals lies, and when it has been crossed. ${ }^{66}$ But as we have seen, conceptually delineating that boundary is a difficult matter. An alternative approach might be to turn the study of boundaries from a conceptual issue to an empirical one. Franklin argues that the site for rehearsing boundaries and transgressions is sociological, and that the process has in some senses begun. ${ }^{67}$ For example, research on cultural constructions of new reproductive and genetic technologies like IVF and preimplantation diagnosis might offer an analogue for discussion about human-animal chimeras. Franklin notes that anthropological research has shown notions such as relationality, kinship, affinity and inheritance are frames of reference within which people work through the desire both to and not to limit genetic technologies. It might be reasonable to guess that these concepts might also frame reactions to genetic technologies that cross animal boundaries, particularly

Genomics, Society and Policy, Vol.3, No.2 (2007) ISSN: 1746-5354

(C) ESRC Genomics Network. 
if it is easier to demonstrate essential continuity between animals and humans than to define difference. Franklin concludes that it is necessary to understand and explicate the sociological principles through which our 'genomic future' is being shaped, allowing us to predict and rehearse when technologies like those that make animalhuman chimeras are most likely to become problematic.

Experience already tells us that ethical or other arguments against such technologies are challenged by the chance that they might save someone's life, and otherwise "repugnant" technologies become acceptable or even imperative. Bailey for example urges the use of infant baboons as heart donors for infant humans. Bailey performed such an operation in 1984, the human infant Baby Fae living for 20 days before the heart was rejected. For Bailey, the argument for such a procedure is clear:

\section{'baboons are a plentiful, unthreatened, largely homologous, versatile donor resource that should be further investigated for this purpose. They are utilized widely in laboratory research ... Immature baboons should not be dismissed as potential donors for young infants unless, or until, they are proved through laboratory or clinical research to transfer infections'.68}

That baboons are numerous and already subjects of scientific procedures are not reasons for their exploitation as organ donors, yet all the same it is not straightforward to argue against the saving of an infant's life, even if a baboon's is lost. But Franklin's point is that we should seek to explore these ethical and moral conundrums before we face stark imperatives, before we even know, for example, if it is technically possible to create hybrid embryos by fusing human cells with rabbit eggs, a proposal widely discussed in the press. ${ }^{69}$ Some of the necessary sociological work will be to look at the positioning and construction of scientific research that crosses given species boundaries by those proposing to do it, those who challenge it, those who regulate it, and those who might have to live with the consequences of it. In this vein, several studies have begun to investigate lay and expert practical reasoning around technologies that transgress species barriers.

Although Bailey recommends the baboon as donor, scientific research and the weight of consensus focuses on the pig. Brown and Michael investigated the criteria used by scientists to legitimate this selection, and the way that they defended their work against negative representations. ${ }^{70}$ They found that scientists drew asymmetrically on the resources of sameness and difference when justifying using pigs rather than the more immediately obvious nonhuman primates. For example, the scientists emphasised that culturally and ethically, pigs are different to humans in a way that other primates are not, and so pigs can be categorised differently, ethically speaking. But technically speaking, they stressed that pigs are the better candidate because they are more similar; for example their organs are of more similar size throughout the lifespan than are those of primates. Brown and Michael show how scientists moved between these scientific and cultural discourses in order to present their work as unproblematic. 
An underlying assumption of social science research of this type is that declarations of sameness and difference are rhetorical achievements, not "natural" categories: they are contingent, tied to the historical moment or an actor's social location and could therefore be otherwise. The political (and policy) edge to this work is that if this is the case, then on what grounds can any one account be privileged? Brown and Michael suggest that experts qua experts assume the facticity of their accounts and present their knowledge as wholly unproblematic to public groups. But public groups are not straightforwardly receptive. In a later work, Michael and Brown analyse conversations between lay people discussing xenotransplantation. ${ }^{71}$ Noting that much expert assessment of technologies is couched in terms of cost-benefit analysis (Bailey above compares the benefit of transplant to the cost of zoonoses) they show that for lay people, cost-benefit is a highly contingent concept. For example, participants reasoned that they needed to trust experts providing information on which any costbenefit analysis could be made, and moreover, needed to make a discriminatory judgement regarding whose costs and benefits to believe.

This asymmetry between expert and lay assessment can have significant consequences for the future trajectory of a given technology, and the science community is not unaware that mixed-species embryos might provoke public disquiet. ${ }^{72}$ Grove-White et al argue that that the late 1990s' public backlash against GM crops developed from areas of tension between the public on the one hand, and industry, Government and "sound science" on the other. ${ }^{73}$ Now research by Macnaghten suggests similar tensions for GM animals. ${ }^{74}$ Macnaghten observed public mistrust toward those institutions seen as responsible for such work combining with a view that GM animals are not 'natural' and that our 'moral' responsibility toward animals is being breached. Macnaghten warns that for GM animals, public controversy is likely.

If something positive came out of the intense and often acrimonious public debate on GM crops and foods in the UK, it is that it catalysed the current interest in upstream public engagement in science policy, ${ }^{75}$ and for animal genomics there is some prospect for the development of new participatory modes of regulatory development. For example, the regulatory status of different human-animal chimeras is not yet wholly fixed and the human-rabbit experiments mentioned above exposed a regulatory grey area centred on whether the resulting embryos could or would be considered "human". The situation is complex too for human-mice chimeras, and the legal and regulatory landscape is as unclear as the moral and the ethical. ${ }^{76}$ Yet this lack of clarity could be turned into an opportunity for the creation of a socially robust policy and regulatory agenda. This will require "social intelligence" on public and expert opinion, and so becomes an opportunity for social science.

\section{The maintenance of borders: genomics, traceability and surveillance}

Haraway locates the "problem" of transgenic organisms in a challenge to the "sanctity of life' maintained in Western cultures, which historically have been obsessed with racial purity, categories authorised by nature and the well-defined self. ${ }^{77}$ Whilst this diagnosis sensitises us to the contingency of common unease at GM animals, it does not remove the sociological fact that by showing how permeable they are, these

Genomics, Society and Policy, Vol.3, No.2 (2007) ISSN: 1746-5354

(C) ESRC Genomics Network. 
technologies problematise received borders between species and between individuals. In contrast, other genomic technologies are concerned not with crossing borders, but with maintaining and policing them.

The movement of animals and animal products within and across nations presents significant challenges for control. Mitchell et al report that within Britain alone, there are around 19 million farm-to-farm cattle movements annually. ${ }^{78}$ In the search for improved tools for tracing movements, genomics can now be applied to the identification of individual farm animals, herds or animal products. For example, DNA sequence variation between individual animals, the principle behind the barcoding approach discussed above, allows the traceability and certification of animal products at any point from farmyard to consumption, to verify the quality and the breed origin of meat or to verify pedigree. ${ }^{79}$ Several companies now offer these services, such as Pyxis Genomics in the United States and the Irish company IdentiGEN, whose 'TraceBack' system uses DNA profiles to track meat back to the individual animal of origin, guaranteeing $100 \%$ traceability. ${ }^{80}$ In one particular case, Sygen developed DNA tracing technology to verify meat from a rare English pig. Meat from Berkshire pigs sells for up to three times more than other pork in Japan, but more pork claiming to be Berkshire was on the market than animals available to supply it. The DNA test exploits variation involved in colour and other physical characteristics between Berkshire and other pigs. ${ }^{81}$

A particularly urgent utility for DNA fingerprinting technology lies with the traceability and containment of disease. "Biosecurity" (the attempt to ensure the health of animals, humans, ecologies etc.) in the form of "surveillance" arrived on the farmyard in the wake of the UK foot and mouth disease epidemic in $2001^{82}$ and surveillant genomic technologies are now being presented as solutions to biosecurity issues. For example, within the EU, high value is placed on accurate and secure animal identification for the monitoring and eradication of disease, but Cunningham and Meghen argue that current technologies, based largely on ear tagging and national databases, are flawed. ${ }^{83}$ They point out that tag switching can disguise a diseased animal for sale, or identify a healthy animal as diseased for compensation. Animal theft and smuggling also challenge conventional tracing procedures. They conclude that DNA technology offers a powerful means of authenticating and controlling animal identification.

The application of genomics to matters of surveillance and control is clearly a policy issue, but currently there is little social scientific input or research. The design and implementation of policy requires a complex set of processes as well as processors, and social scientists can usefully "get amongst" these to facilitate successful policy implementation and to investigate intended and unintended social and economic consequences. For example, from an industry perspective, the need for genomic based technologies is sometimes framed as a means to restore consumer confidence in meat foodstuffs. ${ }^{84}$ But I have already noted that trust is a sufficiently complex sociological phenomenon that, if there is a lack of confidence in meat production, mere technical solutions may not be adequate for its restoration. 
There is also an opportunity for more theoretical and conceptual social scientific work concerning the ordering and re-ordering of social relations, the control of space and movement, and the translation of animal bodies into information and data. Some grounds for this can be found in Donaldson and Wood who show the social dimension of disease management through a case study of foot and mouth disease. ${ }^{85}$ The authors point out that disease control and surveillance strategies are rooted in economic and political systems more than the material nature of the disease. They argue that surveillance manifests as a mode of ordering that controls space and movement through the construction of bounded categories, and that the primary unit of control is not bodies (animal or human) but information and activity.

Consider for example the UK National Scrapie Plan (NSP). ${ }^{86}$ This involves a series of breeding strategies intended to increase the number of sheep genetically resistant to scrapie, and the hope is that eventually the disease will be eradicated from the national sheep flock. Genomics has been recruited into this scheme as a tool of categorisation. Surveillance, Donaldson and Wood note, depends on the purity of categories and the cleanest possible demarcations between them. Genomics, in the form of genotyping, is used in the NSP to determine a sheep's resistance or susceptibility to scrapie, generating clear demarcations between desirable and undesirable genotypes. These distinctions are captured in tables and diagrams where sheep are translated into one of 15 possible genotypes. For instance, the 'NSP Ram Genotyping Scheme Consequences Table' for purebred rams displays 15 genotypes ordered into 5 'types'. ${ }^{87}$ For a genotyped ram falling into types $1-3$, no restrictions apply and that ram can be placed on the Ram Register, a facility to aid the sale or loan of resistant rams. But if a ram turns out to be type 4 or 5 , then an immediate restriction is placed on the sale, transfer or breeding of that animal and it must be slaughtered or castrated within 90 days.

Although the disappearance of type 4 and 5 rams from the gene pool will be considered economically advantageous, the consequences for each ram of the translation of its corporeality to data and back by and through a network of actors and centres of calculation can be fatal. ${ }^{88}$ Yet this represents more than a disregard for that animal. The NSP shows how genomics can facilitate the translation of animal bodies into information and, by making them simply data stored at centralised locations remote from that animal or traditional agents of control (eg, farms and farmers), the instrumental or mechanistic representation of animals is complete. This representation is clearly seen in the industrial application of animal genomics on the farmyard.

\section{Farmyard supermodels}

In his article $A$ Short, Meat-Oriented History of the World, Cockburn notes that the meat industry is Cartesian in outlook and considers animals merely machinery. ${ }^{89} \mathrm{He}$ quotes an executive from a meat company saying that sows should be thought of, and treated as, valuable machines whose function is to pump out baby pigs like sausages. This casting of animals in instrumental and mechanistic terms fits seamlessly with the language and practice of farm animal genomics. 
Genomics, in the form of genome analysis, marker assisted selection and genetic modification, offers an opportunity to intensify the industrial productivity of animals. Raadsma and Tammen neatly encapsulate this materialist objective when they note that genomic technologies will (social factors permitting) lead to the development of 'novel and high value products' and 'opportunities for the mass production of elite males for use in extensive animal production systems'. ${ }^{90}$

For example, the identification of genes associated with particular traits enables informed selection and breeding strategies and/or genetic modification to create animals with new or improved characteristics, or to remove undesirable traits. To illustrate, pork contributes $43 \%$ of the worlds consumed red meat and research at the genomic level attempts to identify candidate genes for efficient growth rates, reproduction, litter size, disease susceptibility, carcass merit (eg, intramuscular fat) and meat quality (eg, tenderness, colour). Using marker-assisted selection, this information is being used within the pig industry to improve pig production. ${ }^{91} \mathrm{~A}$ recent World Health Organisation report outlines many other examples in production or planning, including transgenic salmon that grow 3-5 times faster than their nontransgenic counterparts, cows that produce protein-rich milk to increase the efficiency of cheese production, and chickens with two active ovaries for increased egg production. $^{92}$

These "farmyard supermodels" are something of an achievement for farm animal genomics. The phrase "farmyard supermodels" came from an aside made by a presenter at an international farm animal genomics conference. Following presentations on progress in chicken and bovine genomics, this presenter showed that pig scientists too had their own 'supermodels' with a picture of a sow suckling a particularly large number of piglets. In terms of 'farm level performance' and the production of progeny this sow was exceptional, and throughout the conference many other examples of high performers - pigs with minimal back fat, chickens with extra strong legs to hold extra large bodies, cows with exceptional 'carcass merit' and so on - were displayed.

The continuity between modern breeding informed by genomics and ancient animal breeding is often stressed. ${ }^{93}$ But it was with the rise of market economies, when animal products become commodities, that selection started to focus on productivity, ${ }^{94}$ and it is likely that, informed by the knowledge of the action of thousand of genes, ${ }^{95}$ industrial interest and the weight of private finance will focus on production traits. Yet farm animal genomics is not concerned only with such traits. The centrally funded UK Biotechnology and Biological Sciences Research Council lists product quality and efficiency as only one of three applications of farm animal genomics alongside farm animal health and welfare, and human health. ${ }^{96}$

For the latter, the BBSRC and Roberts argue that farm animals offer particular advantages over the more typical mouse for understanding fundamental biology and for furthering biomedical research (although see section 5 below). ${ }^{97}$ More directly, over twenty companies worldwide are involved in the production and harvesting of therapeutic proteins from transgenic animal "bioreactors" in a process known as pharming. ${ }^{98}$ In June 2006, the European Medicines Agency announced approval of

Genomics, Society and Policy, Vol.3, No.2 (2007) ISSN: 1746-5354

(C) ESRC Genomics Network. 
the first drug produced in an animal bioreactor. ${ }^{99}$ GTC Biotherapeutics' ATryn is an anti-clotting agent for use in people who lack the natural anticoagulant protein and is harvested from transgenic goats. As in this case, proteins are usually gathered from the animal's milk, but attention is also turning to eggs, urine and semen. ${ }^{100}$

In terms of animal health and welfare, research can involve identifying at the genome level disease susceptibility or resistance (such as in the NSP), ${ }^{101}$ but genomics also targets less obvious concerns. Researchers at the Roslin Institute have used genome analysis to investigate genetic variation in nitrogen and phosphorous excretion by poultry, and the feasibility of reducing this by genetic selection. This would address terrestrial and aquatic pollution as well as improve the environment for poultry, farm personnel and nearby residents. ${ }^{102}$ Genetic selection or modification is also being used to select against behaviour that contributes to welfare problems, and genomics holds promise for "improving" welfare by, for instance, enabling animals to better "tolerate" unfavourable conditions, or removing behaviours that lead to distress or increased rates of mortality. For example, piglet mortality is a major welfare and economic problem in the pig industry. Around $12 \%$ of deaths are the consequence of crushing by the sow, and some sows crush more piglets than others. Observing these differences could be used to support a culling regime, or if differences between sows could be shown to have a genetic component, a selective breeding programme. This could involve genomic research, identifying and selecting specific genotypes. ${ }^{103}$

This work is indicative of an increased attention to animal welfare and a considerable body of European and UK legislation, together with popular concern and action toward welfare (eg. growing demand for free range animal products, demonstrations against farm animal transportation) suggests the growth of an 'animal welfare consciousness'. ${ }^{104}$ Whilst this consciousness might be threatened by any increase in animal research or intensification of agriculture flowing from genomic research, genomics can, like for the pigs and chickens, address welfare problems. There are however at least two reasons to suggest that, again, mere technical solutions may be unsatisfactory.

First, it is a utilitarian or cruel-to-be-kind welfare solution that eliminates or slaughters some animals so that "better" ones may survive. Roberts points out that flowing from animal genomics will be "no major effort to coax a genetically infertile sow to reproduce, for example. Flocks and herds will likely be screened for undesirable alleles and affected animals culled from the population'. ${ }^{105}$ This is a human- not animal-centred mode of ordering, a mode organised on economic principles legitimised by appeal to moral concern. This connects to the second reason. Buller and Morris argue that the gradual pervasiveness of animal welfare policy and regulation legitimates the continued subjugation of animals founded in modernity:

'Farm animals, those 'docile bodies', have become vehicles for capitalist accumulation through processes of selection, breeding, intensive husbandry and now genetic modification'. ${ }^{106}$

In the face of this 'modernism re-embedded', Buller and Morris urge two things: the recognition of animals as sentient beings with 'individual animalian distinctiveness'; 
and a new and more individualistic approach to welfare and farming that takes account of the affective and interactive relations between humans and non-humans. The first proposition argues for the reorientation of relations toward the horizontal over the hierarchical, whilst the second suggests that on-farm as well as other relations are psychological and social first, technical second. As Tisdell, and Schakel and van Broekhuizen show, breeding is not merely a technical matter, but a socioeconomic and cultural one, too, ${ }^{107}$ and this, perhaps surprisingly, holds for the laboratory animal.

\title{
5. Laboratory supermodels
}

Some of the hardest working and most numerous animal supermodels are in laboratories. According to a report in Nature, animal research facilities are overflowing with 'mutant mice' and face a multi-million dollar logistical nightmare. For this, 'overworked animal technicians can blame genomics'. ${ }^{108}$ The mouse genome was completed in draft in 2002 and excitement within the science community has been as difficult to contain as the mice. ${ }^{109}$ Garanga describes the completion as a 'watershed that forces us to re-consider our conceptual tools and the way we do research', and Gunter and Dhand suggest that for many, the mouse genome 'holds more promise for our future than even the human genome itself' ${ }^{110}$ This is because the mouse is the experimental model for human biology, and in 2003 mice were involved in around $65 \%$ of all animal experiments in the UK. ${ }^{111}$ The completion of the mouse genome reinforces and extends this distinguished position:

\begin{abstract}
'there can scarcely be a major area of mammalian biology or medicine to which mouse studies have not contributed in some way, often as surrogates for human studies ... Much of this power has come from technologies to manipulate the mouse genome, but until now we have in effect been shooting in the dark. The genome of Mus musculus will provide the necessary illumination'.
\end{abstract}

The study of genetic disease using mice can be based on natural variants, natural mutants, chemical- or radiation-induced mutants, or engineered mutants, and can be used to understand the role of specific genes in monogenic and multifactorial diseases such as type 2 diabetes and sensorineural deafness. ${ }^{113}$ Particular interest is focused on the utility of "knockout" mice, and a project recently announced will "knockout" or disrupt each of the 20,000 protein-coding genes in the mouse genome. ${ }^{114}$ Mice are also important in stem cell research, broadening the utility of the mouse to mammalian development and physiology. Recent advances in this field, attributable to the mouse, are presented with equal enthusiasm. Smith claims that 'the faculty for propagating pluripotent stem cells from mouse and human embryos' is a 'gift from nature [that] has provided unparalleled research tools'. ${ }^{115}$ I noted above, for example, that researchers have experimented with injecting human embryonic stem cells into mouse brains, providing new models for studying neural development which might advance understanding of neurodegenerative and psychiatric diseases.

This enthusiasm and the technical advance of animal models is tempered and constrained by legislation in ways that can usefully be explicated by social science. 
The regulatory and legislative position on animal experimentation seeks to satisfy the requirements of industry and science whilst protecting animals from avoidable suffering and unnecessary use. ${ }^{116}$ This inevitably leads to cost-benefit thinking, but the UK Animal Procedures Committee, which advises the Home Secretary on matters that fall under the Animals (Scientific Procedures) Act, points out that cost-benefit analyses involve judgements that encode values and are therefore contestable and contingent. ${ }^{117}$ They do not, for example, encode the judgements of those who argue for the complete end to animal experimentation in any form.

When grounded ethically, the argument for the end to animal experimentation lacks force, in Burkhardt's terms, in that those involved in the practice of biotechnology will never be persuaded; not, that is, until ethics becomes a legitimate and routine part of the 'scientific attitude'. ${ }^{118}$ This seems to imply that animal scientists don't have ethics, but of course this is not the case. Social scientists are not often directly involved in philosophical analysis of ethics, but they certainly are interested in the ethical and moral reasoning and activities of those engaged on both sides of Burkhardt's binary: with animal rights activists and with animal scientists. ${ }^{119}$ Yet to report, the Reconfigurations of Human/Animal Relations in Genomics and Beyond project at Cesagen, Lancaster University, engages with animal scientists as part of its work, exploring how they frame their research and work through moral dilemmas. ${ }^{120}$ Similarly, the Use of Animals in Science project based at the Institute for Science and Society, University of Nottingham, aims to investigate arguments used by scientists and animal activists and whether and how boundaries are drawn between "ethical" and "scientific" claims. ${ }^{121}$

Other social scientific studies, notably at Innogen, University of Edinburgh, have begun to investigate the commercial activities of the animal genomics sector, the likely socio-economic impacts of new developments, and the international regulatory climate for GM and cloned animals. ${ }^{122}$ The social scientific investigation of laboratory animal genomics is then beginning to hit its stride. There remains however a tendency to orient to the production of human and institutional practice, agency, cognition and so on. But taking a small step from social science toward the history of science, there have been projects that have focused on, and sought to account for, the construction of the animal in scientific research. ${ }^{123}$

In Making Mice, Rader considers the construction of standardised laboratory mice. ${ }^{124}$ Rader points out that scientists tend to produce a laundry list of material features that make the mouse appear without question the most suitable experimental model for human disease states. Garanga lists high fertility, genetic tractability, short gestation and susceptibility to disease, to which Cox and Brown add numerous genetically welldefined lines, modest cost and short generation times. ${ }^{125}$ To this can now also be added the many sophisticated technologies for manipulating the mouse genome and the availability of the genome sequence. ${ }^{126}$ Yet, just as with the pig in xenotransplantation, Rader contends that these justifications need to be understood as the outcome of a historical and sociological process more than the material nature of the mouse. This is not to say that high fertility, modest cost and so on are not valid reasons for choosing the mouse, but that to speak only in these terms decontextualises the mouse and "black-boxes" the places, values, politics and practices that led to its 
development and use as the experimental model. Rader argues that the very notion of a "standardised" laboratory organism required intense negotiation over material, organisational and conceptual categories that are now taken for granted:

'Standardized organisms, therefore, need to be reconceived within a broader sociology of technoscientific work. These animals are the result, rather than the cause, of consensus among early twentiethcentury experimental biologists'.

In discussing the various developers, producers and users of the laboratory mouse, Rader focuses primarily on the role of individuals, especially the 'passion and drive' of Clarence Cook Little. Little founded the Jackson Laboratory in the 1920s which is now home to around 2800 mouse varieties as breeding mice, frozen embryos or DNA samples. ${ }^{128}$ These inbred mice, and all the others in labs across the world, are an allegory of animals under the human gaze.

\section{Knowing, relating and looking at animals}

The position of animals in the human gaze is ambiguous, and these ambiguities function at individual as well as societal and cultural levels. Animals are at times considered companions, members of the family even, and significant resources are deployed in saving particular species, especially when threatened by human activity. At the same time, research that ultimately destroys animals is conducted to better human health, and animals are destroyed or exploited for food, clothing and pleasure. Rats exemplify ambivalent identity, being loveable pets, detestable pests and scientifically 'neutral' laboratory animals. ${ }^{129}$ On an individual level, hobby-farmers experience animals as both friends and sources of food, and those working in the meat industry need to manage both emotional attachment and detachment to the animals with which they work. ${ }^{130}$

It is tempting here to use the conjunction but not and to better capture the apparent paradox in these relationships: to the hobby farmer, animals are friends but also food; rats are pets but also killed for research; some species are conserved but others are hunted as pests. Berger suggests that our temptation to see but here is a vestige of a shift in human-animal relations during the industrial period. ${ }^{131}$ At that time, a previous intimate and proximal relationship where animals were, and meant, many things (...and...) became one of distance, and some animals and some species were reduced to productive units (...but...). Yet following the collapse of modernism and the rise of late modernity/post-modernity, Franklin argues that we must return to seeing the and: 'The possibility of consistency in the realm of human-animal relations', writes Franklin, 'is less likely than differentiations' ${ }^{132}$ Genomic research needs to be understood in the context of this inconsistent and ambiguous landscape, reinforcing the need to think through and talk about human-animal relationships, representations, understandings, practices and so on.

Consider companion animals. Serpell cautions against aligning the companion animal genome with a human aesthetic that disregards effects on the animal. Serpell particularly targets negative consequences arising from genetic selection, noting that 
selection for traits that appeal to our anthropomorphic perceptions has led to animals with painful or disabling conditions, citing the English Bulldog which suffers physical deformities and nasal and respiratory disorders. If the Bulldog had been produced through genetic engineering in agriculture, Serpell suggests, then there would be public protest, but it has been generated by 'anthropomorphic selection' and is accepted because it is part of a social, rather than economic or industrial, inter-species relationship. ${ }^{133}$

Serpell's analysis suggests that if technologies like genetic modification or markerassisted selection become tools of the pet trade, then a different reaction might be expected than to their use in farming or agriculture. ${ }^{134}$ But a reaction would be elicited only if these practices became common knowledge: breeding in agriculture has produced Bulldog-like horrors. Selection for production traits has generated diseases and disabling deformities in poultry that are not seen in animals that have not been selected for rapid growth, ${ }^{135}$ and perpetuating the massive double-muscling cattle breed Belgian Blue, initially the outcome of a 'natural' genetic mutation, presents significant welfare problems. For example, $90 \%$ of Belgian Blue calves have to be delivered by caesarean section and Webster suggests that this runs close to contravening British law and the Protection of Animals Act. Webster argues that 'the whole [Belgian Blue farming] system depends absolutely on the deliberate production of a population of fundamentally unfit breeding animals, lethal recessives in fact' ${ }^{136}$

It may be, therefore, that Serpell's observed lack of public disquiet over such horrors is a consequence of the persistent separation in Western culture of the food we eat from the means of its production, and that we don't really "know" our food animals at all.

However, the rise of the "welfare consciousness" is leading industry and farm animal scientists to consider trade-offs between maximising production whilst at the same time attending to welfare concerns, a process in which functional genomics may have a role. ${ }^{137}$ But whether this solution fits with the needs and demands of the perceived target group - consumers - is a space for social scientific research. It may be that without this research, the technical drive to balance profits and ethics assumes too much about the social world to which it believes it is responding, the type of blind spot sociologists feel led, in part, to the current unstable position of GM crops and food.

Genomics might then be used as a conduit for explicating the varied understandings and relationships which we have with animals, but there are more immediate ways that current genomic practices and technologies change our understandings of animals. For example, by interfering in inherited characteristics, it is sometimes claimed that we are changing the animal that is known, what that animal "is", its "natural" form of life, its purposes and ends ("telos"). Whilst "traditional" animal farming works with those ends, genomic knowledge and biotechnology means that we can manipulate these ends to the point that they are disregarded. ${ }^{138}$ The extent to which this principle is new to biotechnology can be overplayed. Sixty years ago Collingwood commented that for a cattle-breeder, an improved form is one better suited to that breeder's interests, and these are not identical to that of the cattle. ${ }^{139}$ But 
the projection of animals from genomic science is different. For example, Grasseni argues that biotechnology has shaped farmers' perception of animal nature and their practice of animal breeding to fit its patterns. ${ }^{140}$ From ethnographic research at cattle fairs and farms in Italy, Grasseni shows how the 'science' of biotechnology has completed the industrialisation of animal bodies by shaping the 'art' of animal breeding and the 'vision' of cattle breeders. Standardised practices, expert advice and biotechnology now mediate breeders' more direct knowing of their animals and has shifted their concern from 'longevity' and 'sturdiness' to 'productivity' and 'statistical hazard control'.

The central organising principle is that biotechnology and genomics encourages a reductionist view of the animal. Michael argues that 'off the peg' genetic design reduces the animal to the sum of its genes, and the knowing of an animal's genetic make-up becomes enough to comprehensively know that animal. ${ }^{141}$ For Bowring, this breaking up of animals into collections of genes and traits, whose relationship to the organism in which they reside is wholly contingent, and then manipulating genetic material accordingly, threatens the integrity and autonomy of animals on which the human-animal social relationship is based. Bowring argues animal companionship points toward the cultural position of animals as providers of 'aesthetic, affective and cognitive nourishment' in a way that genes clearly cannot, and he argues that a farmer's respect 'for organisms as organisms' is threatened by the genetic engineer and their laboratory. ${ }^{142}$

\section{Concluding remarks: Policies in the genomic era}

For Franklin, the anthropocentric separation of humans and animals is no longer tenable at either the social or theoretical level. ${ }^{143}$ Through its various forms, genomics and associated biotechnologies offer new levels of analysis and new practices for the continued revision of the human-animal conceptual coupling, for the meaning of humanness, and for the representation of animals. Comparative genomics speaks confidently of concepts and tools to quantify the similarity and difference between animals where we might previously have seen predominantly qualitative (humanother) distinctions; stem cell research and cross-species transplantation mix material and make indeterminate hybrid beings; mice are bred to express human genetic defects and become humans by proxy; animals are reduced to information, genes, proteins, etc. temporarily assembled in valuable machines; and so on. For some, these are not only conceptual and sociological issues, but policy issues too.

Paula argues that genomics extends discomfort over the use of animals in science and food production beyond welfare and the "Three Rs" paradigm (replacement, reduction, refinement). Paula suggests that a constellation of intrinsic (eg, tampering with nature) and extrinsic (eg, food safety) citizen concerns, coupled with societal demands for regulatory transparency and accountability, requires a more open and inclusive discussion of animal genomics, which continually moves with technological developments, freely conceiving and discussing them and shaping the research agenda. ${ }^{144}$ 
A challenge for this evolving view of policy is to build mechanisms into decisionmaking by which conceptual framings that fall outside the dominant technical discourse can at least be entertained and thought through. For example, some scientists have been pressing for a 'whole-animal' approach to farm animal welfare. This treats animals as integrated and experiencing beings, and looks at animals' expressive body language in order to understand the "inside" of their experience. Wemelsfelder et al have no hesitation in making theirs an anthropomorphic approach, even inviting lay persons to evaluate animal welfare and validate their approach by considering how an animal seems to be feeling or reacting. ${ }^{145}$ Crucially, these people are only "lay" in the sense that they are not scientists, not in the sense that they cannot understand or know how an animal "feels". This approach contrasts sharply with the currently accepted "scientific" and "objective" assessment of suffering which, for example, counts skin lesions or maladaptive behaviours. It also contrasts sharply with reductionist visions encouraged by genomics.

But notions of species integrity and telos fall outside current regulatory frameworks, and so too do some new scientific animal objects. There are now technologies, practices and products that traverse or transcend the boundaries between regulatory authorities and their terms of reference. ${ }^{146}$ For example, there is no specific UK regulation with regard to the transplant of human stem cells into animals, but depending on the precise procedure and the precise materials, one or more of four different agencies might be involved in granting approval (Home Office, Animal Procedures Committee, Human Fertilisation and Embryology Authority (HFEA), Stem Cell Bank Steering Committee). Although complicated, at least the regulatory procedure is defined. This was not the case when in November 2006 the HFEA received two applications for a licence to derive stem cells from 'human' embryos created from animal eggs instead of human eggs. The embryos would contain animal and human DNA, and an HFEA spokesperson commented that 'we need to decide whether the law prohibits this research [and] whether it falls under our remit at all', clearly illustrating the challenge to existing structures posed by novel creatures. ${ }^{147}$ In January 2007, after 'careful consideration', the HFEA determined that 'under current legislation, these sorts of research would potentially fall within the remit of the HFEA to regulate and license, and would not be prohibited by the legislation'. ${ }^{148}$ But the HFEA decided that the legality of the research alone should not determine the granting of any licence. Rather, the HFEA decided to organise a public consultation on hybrid and chimera research in order to help determine the best way to proceed. ${ }^{149}$ Stephen Minger, head of one team that wants to make the embryos, stated that they were 'happy with [the] decision to consult both public and scientific opinion regarding cloning of human cells using non-human eggs', ${ }^{150}$ perhaps reflecting the new mood for dialogue on science policy issues. ${ }^{151}$ This is a positive development, and I mentioned earlier that animal genomics may be a useful test bed for new ways of developing socially sensitive policies, for it is neither so new that its social consequences cannot be known or predicted, or so established that it is very resistant to change. ${ }^{152}$

Any new process of policy development would need to be anticipatory and reactionary, taking account of developments as they arise. After all, there will always be developments that just a few months or years before were not within the regulatory

Genomics, Society and Policy, Vol.3, No.2 (2007) ISSN: 1746-5354

(C) ESRC Genomics Network. 
gaze or were considered science fiction, and genomics has one more surprise. For a while there has been discussion on the possibility of using cloning techniques to resurrect extinct animal life. ${ }^{153}$ Adding fuel to the discussion, the sequencing of Mammoth DNA ${ }^{154}$ and the finding of the best preserved mammoth yet ${ }^{155}$ led to inevitable media speculation on the possibility of 'growing' a woolly mammoth. ${ }^{156}$ Discussion continues on whether cloning will allow us to come to "know" extinct animals. But perhaps a more important question is: what would we do with a Woolly Mammoth?

${ }^{1}$ The research for this paper was conducted at the ESRC Genomics Policy and Research Forum, University of Edinburgh, UK. Correspondence matthew.harvey@,royalsoc.ac.uk The views expressed in this paper are the author's own.

${ }^{2}$ Eg, M. Michael. Technoscientific Bespoking: Animals, Publics and the New Genetics. New Genetics and Society 2001; 20 (3): 205-224; M. Michael and N. Brown. The Meat of the Matter: Grasping and Judging Xenotransplantation. Public Understanding of Science 2004; 13: 379-397; P. Macnaghten. Animals in Their Nature: A Case Study on Public Attitudes to Animals, Genetic Modification and 'Nature'. Sociology 2004; 38 (3): 533-551; N. Brown and M. Michael. Switching Between Science and Culture in Transpecies Transplantation. Science, Technology \& Human Values 2001; 26 (1): 3-22.

${ }^{3}$ Eg, S. Franklin. Drawing the Line at Not-Fully Human: What We Already Know. The American Journal of Bioethics 2003; 3 (3): W25-W27.

${ }^{4}$ Eg, J. Robert and F. Baylis. Crossing Species Boundaries, American Journal of Bioethics 2003; 3 (3): 1-13; A. Holland and A. Johnson (eds.). 1998. Animal Biotechnology and Ethics, London: Chapman and Hall; F. Bowring. 2003. Science, Seeds and Cyborgs: Biotechnology and the Appropriation of Life, London: Verso (especially chapter 5); M. Hauskeller. Telos: the Revival of an Aristotelian Concept in Present Day Ethics. Inquiry 2005; 48 (1): 62-75.

${ }^{5}$ A. Muotri et al. Development of Functional Human Embryonic Stem Cell-Derived Neurons in Mouse Brain. Proceedings of the National Academy of Sciences 2005; 102 (52): 18644-18648.

${ }^{6}$ Michael, op. cit. note 2, p.205.

${ }^{7}$ H. Tovey. Theorising Nature and Society in Sociology: the Invisibility of Animals. Sociologia Ruralis 2003; 43 (3): 196-215, p197.

${ }^{8}$ Eg, S. Clark. 1982. The Nature of the Beast - Are Animals Moral? Oxford: University Press.

${ }^{9}$ Eg, A. Manning and J. Serpell. 1994. Animals and Society: Changing Perspectives, London: Routledge; H. Ritvo. 1997. The Platypus and the Mermaid and Other Figments of the Classifying Imagination, Cambridge: Harvard University Press.

${ }^{10} \mathrm{Eg}, \mathrm{K}$. Tester. 1991. Animals and Society: the Humanity of Animal Rights, London: Routledge.

${ }^{11}$ Eg, Holland \& Johnson, op. cit. note 4.

${ }^{12}$ Tester, op. cit. note 10 .

13 cf. Tovey, op.cit. note 7.

${ }^{14}$ Eg, A. Franklin. 1999. Animals and Modern Cultures: A Sociology of Human-Animal Relations in Modernity. London: Sage; L. Holloway. Pets and Protein: Placing Domestic Livestock on HobbyFarms in England and Wales. Journal of Rural Studies 2001; 17: 293-307; R. Wilkie. Sentient Commodities and Productive Paradoxes: The Ambiguous Nature of Human-Livestock Relations in Northeast Scotland. Journal of rural studies 2005; 21: 213-230.

${ }^{15}$ Eg, A. Podberscek, E. Paul and J. Serpell. 2000. Companion Animals and Us: Exploring the Relationships Between People and Pets, Cambridge: University Press.

${ }^{16}$ See I. Diamond and D. Woodgate. Genomics Research in the UK - the Social Science Agenda, New Genetics and Society 2005; 24 (2): 239-252.

${ }^{17}$ There is a joke doing the rounds that there are more social scientists studying stem cell scientists than stem cell scientists studying stem cells. But for sure, few, if any, of those social scientists are investigating the role of animals in stem cell research.

${ }^{18}$ L. Paula. 2003. Genomics and Man's Attitude to Animals: Towards a Sustainable Relationship? In Genes For Your Food - Food For Your Genes: Societal Issues and Dilemmas in Food Genomics, R. van Est, L. Hanssen and O. Crapel, eds. Working Document 92, The Hague: Rathenau Institute; L. 
Paula. Effective Policies in the Animal Genomics Era: How Best to Involve Ethics, Expertise and the Public. ATLA 2004; 32 (1): 383-389.

${ }^{19}$ S.J. Gould. 1996. Dinosaur in a Haystack: Reflections in Natural History. London, Jonathan Cape: 3.

${ }^{20}$ P. Hebert et al. Biological Identifications Through DNA Barcodes. Proceedings of the Royal Society of London B 2002; 270 (1512): 313-321.

${ }^{21}$ B. Holmes. Barcode Me. New scientist 2004; 26 June: 32-35.

${ }^{22}$ Eg, M. Hajibabaei et al. DNA Barcodes Distinguish Species of Tropical Lepidoptera. Proceedings of the National Academy of Sciences of the United States of America 2006; 103 (4): 968-971.

${ }^{23}$ R. Hanner et al. 2005. FISH-BOL Workshop Report (available at http://www.fishbol.org).

${ }^{24}$ See http://barcoding.si.edu/index detail.htm.

${ }^{25}$ Holmes, op. cit. note 21

${ }^{26}$ P. Hebert and R. Gregory. The Promise of DNA Barcoding for Taxonomy. Systematic Biology 2005; 54 (5): 852-859.

${ }^{27}$ Eg, K. Will, B. Mishelr and Q. Wheeler. The Perils of DNA Barcoding and the Need for Integrative Taxonomy. Systematic Biology 2005; 54 (5): 844-851; M. Ebach and C. Holdrege. DNA Barcoding is no Substitute for Taxonomy, Nature 2005; 434: 697.

${ }^{28}$ See Costa and Carvalho, this issue: F.O. Costa and G.R. Carvalho. The Barcode of Life Initiative: synopsis and prospective societal impacts of DNA barcoding of fish. Genomics, Society and Policy 2007; 3 (2): 29-40

${ }^{29}$ Will et al, op. cit. note 27, p.844.

${ }^{30}$ Ebach and Holdrege, op. cit. note 27, p.697.

${ }^{31}$ H. Ritvo. Border Trouble: Shifting the Line Between People and Other Animals. Social Research 1995; 62 (3): 481-499.

${ }^{32}$ Ibid; Ritvo, op. cit. note 9; H. Ritvo. Our Animal Cousins. Differences 2004; 15 (1): 48-68.

${ }^{33}$ J. Dupré. In Defence of Classification. Studies in the History and Philosophy of Biology and Biomedical Science 2001; 32 (2): 203-219.

${ }^{34}$ J. Dupré. 2002. Humans and Other Animals. Oxford: Clarendon Press: 46.

${ }^{35}$ Cf. J. Hey. 2001a. Genes, Categories and Species: The Evolutionary and Cognitive Causes of the Species Problem. Oxford: University Press; J. Hey. The Mind of the Species Problem. Trends in Ecology and Evolution 2001b; 16 (7): 326-329.

${ }^{36} \mathrm{~J}$. Hey 2001a, op cit. note 35.

${ }^{37}$ B. Charlesworth and D. Charlesworth. 2003. Evolution, Oxford: University Press.

${ }^{38}$ B. Herrnstein Smith. Animal Relatives, Difficult Relations. Differences 2004; 15 (1): 1-23 (p.2).

${ }^{39}$ Hansard, 10 January 2006, column 171.

${ }^{40}$ L. Stein. End of the Beginning. Nature 2004; 431: 915-916.

${ }^{41}$ W. Enard et al. Intra- and Interspecific Variation in Primate Gene Expression Patterns. Science 2002; 296: 340-343

${ }^{42}$ For a detailed analysis of the gene-number story and the human genome project, see T. Holmberg. Questioning 'The Number of the Beast': Constructions of Humanness in a Human Genome Project (HGP) Narrative. Science as Culture 2005; 14 (1): 23-37.

${ }^{43}$ J. Hecht. Chimps are Human, Gene Study Implies. New Scientist 2003; 19 May (available at http://www.newscientist.com/article.ns?id= $\operatorname{dn} 3744$ )

${ }^{44}$ D. Wildman et al. Implications of Natural Selection in Shaping 99.4\% Nonsynonymous DNA Identity between Humans and Chimpanzees: Enlarging genus Homo. PNAS 2003; 100 (12): 7181 7188.

${ }^{45}$ Ibid, p.7181.

${ }^{46}$ M. Goodman. Epilogue: A Personal Account of the Origins of a New Paradigm. Molecular Phylogenetics and Evolution 1996; 5 (1): 269-285.

${ }^{47}$ J. Marks. 2003. 98\% Chimpanzee and 35\% Daffodil: The Human Genome in Evolutionary and Cultural Context. In Genetic Nature/Culture: Anthropology and Science Beyond the Two-Culture Divide. A. Goodman, D. Heath and M. Lindee, eds. London: University of California Press: 132-152 (p.139).

${ }^{48}$ Ibid, p.132.

${ }^{49}$ A. Lippman. Prenatal Genetic Testing and Screening: Constructing Needs and Reinforcing Inequities. American Journal of Law and Medicine 1991; 17: 15-50.

${ }^{50}$ What Makes us Human? Channel 4, 12 April, 2006. 
${ }^{51}$ Eg, P. Gagneux and A. Varki. Genetic Differences Between Humans and Great Apes. Molecular Phylogenetics and Evolution 2000; 18 (1): 2-13; E. McConkey and A. Varki. Thoughts on the Future of Great Ape Research. Science 2006; 309: 1499-1501.

${ }^{52}$ I. Van der Ploeg. 2003. Biometrics and the Body as Information: Normative Issues of the Sociotechnical Coding of the Body. In Surveillance as Social Sorting: Privacy, Risk, and Digital Discrimination. D. Lyon, ed. London: Routledge: 57-73.

${ }^{53}$ E. Zuckerkandl and L. Pauling. 1965. Evolutionary Divergence and Convergence in Proteins. In Evolving Genes and Proteins. V. Bryson and H. Vogel, eds. London: Academic Press: 97-166.

${ }^{54} \mathrm{http}: / /$ www.medicalnewstoday.com/medicalnews.php?newsid=47782

${ }_{55}$ A. Ureta-Vidal, L. Ettwiller and E. Birney. Comparative Genomics: Genome-Wide Analysis in Metazoan Eukaryotes. Nature Review Genetics 2003; 4: 251-262.

${ }^{56}$ T. Brown. 2002. Genomes. Oxford: BIOS.

${ }^{57}$ C. Woese. Interpreting the Universal Phylogenetic Tree. PNAS 2000; 97 (15): 8392-8396.

${ }^{58}$ For an image of Darwin's first tree, see R. Winters. The World Through Darwin's Lens. Science 2006; 311: 179 .

${ }^{59}$ E. Koonin, L. Aravind and A. Kondrashov. The Impact of Comparative Genomics on Our Understanding of Evolution. Cell 2000; 101 (6): 573-576.

${ }^{60}$ M. Rivera and J. Lake. The Ring of Life Provides Evidence for a Genome Fusion Origin of Eukaryotes. Nature 2004; 431: 152-155.

${ }^{61}$ V. Kunin et al. The Net of Life: Reconstructing the Microbial Polygenetic Network. Genome Research 2005; 15 (7): 954-959; W. Doolittle. Phylogenetic Classification and the Universal Tree, Science $1999 ; 284: 2124-2128$.

${ }^{62}$ Ibid, p.2127-2128.

${ }^{63}$ Robert and Baylis, op. cit. note 4.

${ }^{64}$ Eg, Ibid; Hauskeller, op. cit. note 4; F. Bowring. Animal Wrongs. New Humanist 2004; 119 (2) (available at http://newhumanist.org.uk/724); Michael \& Brown, op. cit. note 2; Franklin, op. cit. note 3; Macnaghten, op. cit. note 2 .

${ }^{65}$ Eg, P. Karpowicz, C. Cohen and D. van der Kooy. Is it Ethical to Transplant Human Stem Cells into Nonhuman Embryos? Nature Medicine 2004; 10 (4): 331-335; L. Bailey. Candid Observations on the Current Status of Xenotransplantation, Xenotransplantation 2005; 12 (6): 425-426.

${ }^{66}$ C. Cohen. Creating Human-Nonhuman Chimeras: of Mice and Men. The American Journal of Bioethics 2003; 3 (3): W3-W5.

${ }^{67}$ Franklin, op. cit. note 3.

${ }^{68}$ Bailey, op. cit. note 65, p. 428 .

${ }^{69}$ Eg, The Guardian, The Daily Telegraph, The Independent 13 January 2006.

${ }^{70}$ Brown and Michael, op. cit. note 2.

${ }^{71}$ Michael and Brown, op. cit. note 2.

${ }^{72}$ N. DeWitt. Biologists Divided Over Proposal to Create Human-Mouse Embryos. Nature 2002; 420 : 255.

${ }^{73}$ R. Grove-White, P. Macnaghten and B Wynne. 2000. Wising Up: The Public and New Technologies. CSEC: Lancaster University.

${ }^{74}$ Macnaghten, op. cit. note 2.

${ }^{75}$ Eg, ESRC. 1999. The Politics of GM Food: Risk, Science and Public Trust. Special Briefing no. 5. ESRC: Swindon; R. Grove-White et al. 1997. Uncertain World: Genetically Modified Organisms, Food and Public Attitudes in Britain. London: CSEC \& Unilever; C. Marris et al. 2001. Public Perceptions of Agricultural Biotechnology in Europe (PABE). Final Report to the European Commission FAIR CT983844 (DG12-SSMI) (see www.pabe.net).

${ }^{76}$ DeWitt, op. cit. note 72; Karpowicz et al, op. cit. note 65; E. Check. Biotech Critic Tries to Sew Up Research on Chimaeras. Nature 2003; 421: 4.

${ }^{77}$ D. Haraway. 1997. Modest-Witness@Second-Millennium.FemaleMan@_Meets_OncoMouse ${ }^{\mathrm{TM}}$ : Feminism and Technoscience. London: Routledge.

${ }^{78}$ A. Mitchell. Characteristics of Cattle Movements in Britain: An Analysis of Records from the Cattle Tracing System: Animal Science 2005; 80 (3): 265-273.

${ }^{79}$ G. Plastow. The Changing World of Genomics and its Impact on the Pork Chain. Advances in Pork Production 2003; 14: 67-71; E. Cunningham and C. Meghen. Biological Identification Systems: Genetic Markers. Revue Scientifique et Technique 2001; 20 (2): 491-499; J. Vázquez et al. Practical 
Application of DNA Fingerprinting to Trace Beef. Journal of Food Protection 2004; 67 (5): 972-979; A. Eggen and J-.F. Hocquette. Genomic Approaches to Economic Trait Loci and Tissue Expression Profiling: Application to Muscle Biochemistry and Beef Quality. Meat Science 2003; 66 (1): 1-9.

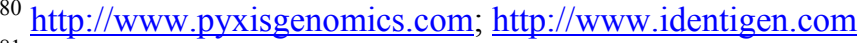

${ }^{81} \mathrm{See} \mathrm{http://news.bbc.co.uk/go/pr/fr/-/1/hi/sci/tech/3751535.stm}$

${ }^{82}$ A. Donaldson and D. Wood. Surveilling Strange Materialities: Categorisation in the Evolving Geographies of FMD Biosecurity. Environment and planning D: society and space 2004; 22: 373-391.

${ }^{83}$ Cunningham \& Meghen, op. cit. note 79.

${ }^{84} \mathrm{Eg}$, Eggen \& Hocquette, op.cit. note 79.

${ }^{85}$ Donaldson \& Wood, op. cit. note 82.

${ }^{86}$ DEFRA. 2006. National Scrapie Plan for Great Britain. London: DEFRA (available at http://www.defra.gov.uk/corporate/regulat/forms/ahealth/nsp/nsp1.pdf)

${ }^{87}$ Ibid, p.22

${ }^{88}$ It is possible however that that ram might continue to "exist" in some sense. Rams that have scrapiesusceptible genotypes can be nominated to contribute toward a semen archive. Whilst the slaughter will still be carried out, if accepted, that ram's genotype will be stored and might be used in the future for breeding. This is because selecting only for scrapie-resistant genotypes might compromise important health and production traits and there may be a time when other political and economic factors will change the constellation of elements desirable in the particular mode of ordering enforced.

${ }^{89}$ A. Cockburn. A Short, Meat-Oriented History of the World: From Eden to Mattole. New Left Review 1996; 215: 16-42.

${ }^{90}$ H. Raadsma and I. Tammen. Biotechnologies and Their Potential Impact on Animal Breeding and Production: A Review. Australian Journal of Experimental Agriculture 2005; 45 (8): 1021-1032 (p.1021), emphasis added.

${ }^{91}$ Eg, M. Rothschild. From a Sow's Ear to a Silk Purse: Real Progress in Porcine Genomics. Cytogenetic Genome Research 2003; 102: 95-99; K. Kim et al. A Missense Variant of the Melanocortin 4 Receptor (MC4R) Gene is Associated with Fatness, Growth and Feed Intake Traits. Mammalian Genome 2000; 11 (2): 131-135.

92 WHO. 2005. Modern Food Biotechnology, Human Health and Development: An Evidence Based Study, Geneva: WHO.

${ }^{93}$ Eg, F. Nicholas. Breeding By Numbers: An Ancient Endeavour That Still Resonates in the Exciting Era of Functional Genomics. Australian Journal of Experimental Agriculture 2005; 45: 735-737; BBSRC. 2005. Review of Farm Animal Genomics in Relation to BBSRC-Funded Research. Swindon: BBSRC.

94 J. Mason and P. Singer. 1980. Animal Factories, New York: Crown Publishers.

${ }^{95}$ Nicholas, op. cit. note 93.

${ }^{96}$ BBSRC, op. cit. note 93.

${ }^{97}$ Ibid; M. Roberts. The Place of Farm Animal Species in the New Genomics World of Reproductive Biology. Biology of Reproduction 2001: 409-417.

${ }^{98}$ R. Das. Production of Therapeutic Proteins From Transgenic Animals. Biobusiness 2001; February: 60-64.

${ }^{99}$ C. Schimdt. Belated Approval of First Recombinant Protein from Animal. Nature Biotechnology 2006; 24: 877

${ }^{100}$ M. Dyck et al. Making Recombinant Proteins in Animals - Different Systems, Different Applications. Trends in Biotechnology 2003; 21 (9): 394-399.

${ }^{101}$ See also J. Clark and B. Whitelaw. A Future for Transgenic Livestock. Nature Review Genetics 2003; 4: 825-833

${ }^{102}$ Roslin Institute. 2005. Reducing Nitrogen and Phosphorous Excretion by Poultry, Annual Report 03/04. Edinburgh: Roslin Institute.

${ }^{103}$ S. Jarvis, R. D'Eath and K. Fujita. Consistency of Piglet Crushing By Sows. Animal Welfare 2005; 14 (1): 43-51.

${ }^{104}$ M. Winter, C. Fry and S. Carruthers. European Agricultural Policy and Farm Animal Welfare. Food Policy 1998; 23 (3/4): 305-323.

${ }^{105}$ Roberts, op. cit. note 97, p.414.

${ }^{106}$ H. Buller and C. Morris. Farm Animal Welfare: A New Repertoire of Nature-Society Relations or Modernism Re-Embedded? Sociologia Ruralis 2003; 43 (3): 216-237 (p.218). 
${ }^{107}$ C. Tisdel. Socioeconomic Causes of Loss of Animal Genetic Diversity: Analysis and Assessment. Ecological Economics 2003; 45: 365-376; J. Schakel and R. van Broekhuizen. Breeding and Society: The Art of Creating New and Multiple Equilibria. Proceedings of the SEFABAR Final workshop 2003 (available at http://www.sefabar.org/).

108 J. Knight and A. Abbott. Full House. Nature 2002; 417: 785-786 (p.785).

${ }^{109} \mathrm{R}$. Waterston et al. Initial Sequencing and Comparative Analysis of the Mouse Genome. Nature 2002; 420: 520-562.

${ }^{110}$ S. Garanga. Preface to Mouse Genetics After the Mouse Genome. Cytogenetic Genome Research 2004; 105 (2-4): 165; C. Gunter and R. Dhand. Human Biology By Proxy. Nature 2002; 420: 509.

${ }^{111}$ Home Office. 2004. Statistics of Scientific Procedures on Living Animals, London: HMSO.

${ }_{112}$ M. Boguski. The Mouse That Roared. Nature 2002; 420: 515-516 (p.515).

${ }^{113}$ R. Cox and S. Brown. Rodent Models of Genetic Disease. Current Opinion in Genetics and Development 2003; 13: 278-283.

${ }^{114} \mathrm{http}: / /$ www.medicalnewstoday.com/medicalnews.php?newsid=51467

115 A. Smith. Embryo-Derived Stem Cells: Of Mice and Men. Annual Review of Cell and Developmental Biology 2001; 17: 435-462 (p.456).

${ }^{116}$ APC. 2001. Report on Biotechnology. London: APC.

117 APC. 2003. Review of Cost-Benefit Assessment in the Use of Animals in Research, London: APC.

118 J. Burkhardt. 1998. The Inevitability of Animal Biotechnology? Ethics and the Scientific Attitude. In Animal Biotechnology and Ethics. A. Holland and A. Johnson, eds. London: Chapman and Hall: 114-132 (p.130).

${ }^{119} \mathrm{Eg}, \mathrm{N}$. Taylor. In it for the Nonhuman Animals: Animal Welfare, Moral Certainty, and Disagreements. Society and Animals 2004; 12 (4): 317-339; R. Einwohner. Motivational Framing and Efficacy Maintenance: Animal Rights Activists' Use of Four Fortifying Strategies. Sociological Quarterly 2002; 43 (4): 509-526; E. Paul. Us and Them: Scientists' and Animal Rights Campaigners' Views of the Animal Experimentation Debate. Society and Animals 1995; 3 (1): 1-21.

${ }^{120} \mathrm{http}: / /$ www.cesagen.lancs.ac.uk/roar/

121 http://www.nottingham.ac.uk/iss/research/Current-Research-Projects/Staff projects/HobsonWest animals.php

${ }^{122}$ http://www.innogen.ac.uk/Research/

${ }^{123}$ Eg, R. Kohler. 1994. Lords of the Fly: Drosophila Genetics and the Experimental Life. London: University of Chicago Press; K. Rader. 2004. Making Mice, Princeton: University Press.

${ }^{124}$ Ibid

${ }^{125}$ Garanger, op.cit. note 110; Cox \& Brown, op.cit. note 113.

${ }^{126}$ J. Rossant and S. Scherer. The Mouse Genome Sequence: The End of the Tail, or Just the Beginning? Genome Biology 2003; 4 (4): article 109.

${ }^{127}$ Rader, op. cit. note 123 , p. 15.

${ }^{128}$ See http://www.jax.org/index.html

${ }^{129}$ B. Edelman. 'Rats are People, Too!': Rat-Human Relations Re-Rated. Anthropology Today 2002; 18 (3): 3-8.

${ }^{130}$ Holloway, op. cit. note 15 ; Wilkie, op. cit. note 15.

131 J. Berger. 1980. About Looking. New York: Pantheon Books.

${ }^{132}$ Franklin, op. cit. note 15, p.2.

${ }^{133}$ J. Serpell. Anthropomorphism and Anthropomorphic Selection: Beyond the "Cute Response". Society and Animals 2003; 11 (1): 83-100.

${ }^{134}$ Advances in genomic medicine (or more accurately, post-genomic medicine) are now being readied for use in veterinary practice. Mian et al describe how genetic bio-profiling and biomarker technology will improve diagnostic and treatment services for pets, personalising treatment for companion animals. S. Mian, K. Slater and T. Cave. The Future of Biomarkers and Personalised Medicine in Companion Animal Practice. EJCAP 2006; 16 (1): 1-9.

${ }^{135}$ R. Julian. Rapid Growth Problems: Ascites and Skeletal Deformities in Broilers. Poultry Science 1998; 77: 1773-1780.

${ }^{136}$ A. Webster. Rendering Unto Caesar: Welfare Problems in Belgian Blue Cattle. The Veterinary Journal 2002; 163: 228-229 (p.229).

${ }^{137}$ Eg, D. Burt. Applications of Biotechnology in the Poultry Industry. World's Poultry Science Journal 2002; 58: 5-13. 
${ }^{138}$ A. Holland. 1990. The Biotech Community: A Philosophical Critique of Genetic Engineering. In The Bio-Revolution. P. Wheale and R. McNally, eds. London: Pluto.

${ }^{139}$ R. Collingwood. 1965/1945. The Idea of Nature. Oxford: University Press.

${ }^{140}$ C. Grasseni. Designer Cows: The Practice of Cattle Breeding Between Skill and Standardization, Society and Animals 2005; 13 (1): 33-49.

${ }^{141}$ Micheal, op. cit. note 3 .

142 Bowring, op. cit. note 5, pp.139 \& 138

${ }^{143}$ Franklin, op. cit. note 15 .

${ }^{144}$ Paula, op. cit. note 19.

${ }^{145}$ Eg, F. Wemelsfelder et al. Assessing the 'Whole Animal': A Free Choice Profiling Approach. Animal Behaviour 2001; 62 (2): 209-220.

${ }^{146}$ N. Brown and M. Michael. Risky Creatures: Institutional Species Boundary Changes in Biotechnology Regulation. Health, Risk and Society 2004; 6 (3): 207-222.

${ }^{147} \mathrm{http}: / /$ news.bbc.co.uk/1/hi/health/6230945.stm

148 Angela McNab, chief executive of the HFEA, quoted in the New Scientist, issue 2564, 11 January 2007 , p.7.

${ }^{149} \mathrm{http}: / /$ www.hfea.gov.uk/docs/HFEA_Final.pdf

${ }^{150}$ New Scientist, issue 2564, 11 January 2007, p.7.

${ }^{151}$ House of Lords Select Committee on Science and Technology. 2000. Science and technology - third report. House of Lords: London.

${ }^{152}$ Paula, op. cit. note 19.

${ }^{153}$ R. Lanza et al. Cloning of an Endangered Species (Bos Gaurus) Using Interspecies Nuclear Transfer. Cloning 2000; 2: 79-90; R. DeSalle and G. Amato. The Expansion of Conservation Genetics. Nature Review Genetics 2004; 5 (9): 702-712.

${ }^{154}$ H. Poinar et al. Metagenomics to Paleogenomics: Large-Scale Sequencing of Mammoth DNA, Science 2006; 311: 392-394.

${ }^{155} \mathrm{http}: / /$ news.bbc.co.uk/1/hi/sci/tech/6284214.stm

${ }_{156}$ Eg, Ibid; BBC News 19 December 2005. 